\title{
Lyrics of the song "Virus Corona" by Rhoma Irama: Stylistic Studies
}

\author{
Moh. Muzakka ${ }^{1}$, Mujid F Amin ${ }^{1}$, Sri Puji Astuti ${ }^{1}$, Dandi Hermawan ${ }^{1}$, and Rizky Devy \\ Wulandari ${ }^{1}$ \\ ${ }^{1}$ Faculty of Humanities, Diponegoro University, Semarang, Indonesia
}

\begin{abstract}
This study aims to describe the language style of the song lyrics composed by Rhoma Irama in response to the global Covid19 pandemic, namely the lyrics of the song is "Virus Corona". The lyrics of this song are very popular because apart from being launched during a long pandemic, Rhoma Irama also often sings the song in search of funds to help people affected by this global pandemic. To describe the language style in the song lyrics, a stylistic approach is used, as an interdisciplinary linguistic approach used to analyze literary works. The data collection method used was a literature study with listening and note-taking. The data analysis used is a stylistic approach with reference to the model formulated by Rahmat Djoko Pradopo. The results of the analysis show that the language style that builds the lyrics of the song "Virus Corona" by Rhoma Irama cannot be separated independently based on the language style units because the discourse of the song lyrics is built by sound style, word style, and sentence-style which is coherent and sublime to build a complete discourse, namely the request for the protection of people to God so that they are free from the Covid-19 epidemic which frightens all mankind.
\end{abstract}

\section{Preliminary}

A very important aspect of literary research in language development is stylistic research. This is because the language style in literary works, in addition to influencing the language style of the readers, can also be used as a measure of change and development of the author's aesthetic insight. Tuner argues that stylistics is a part of linguistics that focuses its attention on variations in the use of language in literary works [1].

One type of literary work is song lyrics because, in essence, the song lyrics are sung poetry. Song lyrics, like poetry, have the same popularity as songs sung by singers, so song lyrics have a wider reach and acceptance in society than other poems. One of the legendary Indonesian singers who is still productive working on creating songs and singing is Rhoma Irama. Throughout his musical career with Soneta Group, which was founded in 1970, he has created many song titles with various themes, namely love, humanity, and religion. In the film repertoire, he has made and acted in his own films as the lead role in more than 20 film titles. 
Studies of the song lyrics by Rhoma Irama have been carried out by many literary researchers. Some of these studies have been carried out by Muzakka in an article entitled "Social Criticism in the Song Lyrics" Indonesia "by Rhoma Irama" (2019) [2]; "Rhoma Irama's Unrest towards Women in the Public Sector: A Study on the Lyrics of the Song' Emansipasi Wanita" (2019) [3]; "Prophetic Values in Two Song Lyrics by Rhoma Irama: Study of the Song Lyrics" Akhlak "and" Virus Corona" (2020) [4], and "Malay Aesthetic Values in Song Lyrics by Rhoma Irama: A Study of "Seni" and "Buta Tuli" (2020).

One of the most popular song lyrics is a song composed and sung by Rhoma Irama when the global Covid 19 pandemic spreads to Indonesia, namely "Virus Corona", which was released in the form of a song in March 2020 [4]. This song is a special song that he made for reflection because it was not released on a special album. However, the song is more of an expression by the author on the problem of the global pandemic. Although Muzakka reviewed the lyrics of the song in 2020, he did not review the lyrics of the song in the stylistic aspect.

The language style research, according to Pradopo can be done in prose and poetry. Because language style is the use of language specifically to get certain effects, what is researched is the form of language and what effects are caused by its use [5]. The form of language in literature stems from the aspects of language that build a literary work. It is through these aspects of language that the sound style, word style, sentence style, and overall style of expression appear in literary works, which is commonly referred to as the discourse style. Starting from Pradopo, the writer will analyze the lyrics of Rhoma Irama's song "Virus Corona" in terms of language style.

\section{Method}

The object of this research is lyrics for the song "Virus Corona" (2020) by Rhoma Irama. The song's lyrics were chosen as the object of research because the song really marks the global Covid-19 outbreak or pandemic. Because the formal object is the study of language styles, the perspective of his study is based on the stylistic approach, which is an interdisciplinary linguistic approach that focuses on literary studies $[5,6,7]$.

This research is included in library research because in revealing the language style of the selected song lyrics the researcher only focused on the study of the song lyrics. The method of data collection is done by observing and taking notes. After the data has been collected in a number of categories, the data is then analyzed carefully using a stylistic approach, namely how sound elements, word elements, phrase elements, and sentence elements build discourse lyrics of the song "Virus Corona". In addition to the style of language in these units, the relationship between the elements in building the language style of the song lyrics is also studied. Related to this, the author tries to apply the stylistic work steps initiated by Pradopo [5].

\section{Discussion}

By considering the appropriateness of writing scientific articles and clarifying the analysis of the song lyrics "Virus Corona", the writer will divide the elements forming language style based on Pradopo's opinion $[5,8]$ into three parts, namely sound style, word style, and sentence style and discourse. 


\subsection{Sound Style}

If we look at the lyrics of the song "Virus Corona", it is full of sound elements in the form of alliteration, assonance, and rhyme. The three of them are very closely related in building the orchestration of the sound so that the lyrics of the song, when read alone, are very melodious, especially when sung, causing the song to become more melodious. This is illustrated by the first couplet consisting of 6 lines, followed by the second couplet consisting of 4 lines. This can also be seen in the fourth and fifth couplet of the lyrics of this song after being separated by the third couplet. If seen from the ending rhyme, all the couplets of the song's lyrics rhyme (aa) even though each couplet has a different number of lines. This is not a coincidence factor but was created by the author to create poetic value, especially to create melodious sounds. In addition to using the same ending rhyme, the song's lyrics are also constructed by the dominant elements of assonance and alliteration to express the soul of the author.

\subsection{Word Style}

The style of words that will be discussed in this paper includes various things as described by Pradopo [5], namely the style of the word form (morphology), the meaning of the word (semantics), and the origin of the word (etymology). With these three stylistic elements, the lyrics of Rhoma Irama's "Virus Corona" will be studied in depth.

From the style of the word form, the diction contained in the lyrics of the song "Virus Corona" varies widely. This can be seen in the use of basic words and complex words. Reduplication words do not appear in the lyrics of this song. As for the use of word groups, both in the form of phrases and compound words is less dominant.

In terms of the meaning of the word, the lyrics of the song "Virus Corona", because they are filled with daily vocabulary, generally have a very straightforward meaning, which is easy to understand when the audience reads or listens to them. Even though using everyday vocabulary does not mean these lyrics are not ethical. However, behind the straightforward meaning, besides being able to build a beautiful and expressive sound style. This choice of words is excellent for constructing rhetorical poetry that aims to convey a strong moral message.

In terms of etymology, almost all of the selected vocabulary comes from Indonesian, although foreign language absorption words (Arabic and English) are also used, which have been standardized in Indonesian, for example, creatures, isolation, viruses, and microbes. There is a foreign vocabulary from Arabic which is used in the song lyrics, namely inayah, which means help. Although the word inayah still appears to be Arabic, it is commonly used in everyday language usage, such as the vocabulary of hidayah, tawadhu ', and so on. So, even though the author has the freedom to choose words, the author in these lyrics does choose the full Indonesian vocabulary.

\subsection{Sentence and Discourse Style}

According to Pradopo, sentence style in literary works includes two main things, namely, the style of sentence form and rhetorical devices [5]. The style of the sentence is formed by the style of the words. Therefore, the style of the words really determines the style of the sentence that is formed, both the style of the sentence and the rhetorical devices. Furthermore, the sentence style forms a higher style unity to express the expression of the author's soul in particular, namely the discourse style that is built into the literary works he writes. 
If we look at the lines of Rhoma's song "Virus Corona", which form the couplets of the poem, they are complex sentences that can be paraphrased into paragraphs. This is because each line of the lyrics for the song "Virus Corona" is closely related to the lines underneath which form the couplet. So, the author is very good at choosing words that have a poetic effect even though the lines in the couplet then form complex sentences that form paragraphs and discourse. The series of lines in the first and second couplets can be chained or paraphrased into complex sentences that are difficult to separate. If the two couplets are connected with more standard sentences, a short paragraph will be created.

This gripping horror has hit humans when the creature (coronavirus) comes to attack and causes many deaths. The Virus was very small, invisible to the eye and could not be touched. However, that creature was terrifying to all humans. Because humans are scared, almost all over the country they close themselves by isolating themselves and hiding.

If in the first and second verses the author describes a frightening atmosphere by taking an endeavour, namely trying to avoid this global epidemic, then in the third couplet, the author emphasizes the spiritual side. Besides making concrete efforts (ikhtiar), the author also asks God for help (inayah) by praying earnestly. With spiritual practice (prayer), the author hopes that this global pandemic will end soon because the presence of the coronavirus on this earth was also created by God. With earnest prayer, the author hopes that God will soon eliminate the Virus that frightens the inhabitants of the earth.

As for the fourth and fifth verses, the author invites us to think and ponder the problem of the plague in a rational and spiritual way. The author also invites readers to respond to the plague by providing solutions, namely with effort and prayer. Efforts are physical efforts such as wearing masks, maintaining distance, washing hands with soap or hands sanitiser, to vaccinations. As for prayer, it is a spiritual effort, namely the request of the servant to God. In essence, the arrival of this global pandemic is closely related to the power of Almighty God.

When examined in terms of the rhetorical means used, the lyrics for the song "Corona Virus" use a variety of figures of speech. However, what dominantly made song lyrics as a whole pleonasm, metaphor, and litotes. Pleonasm is widely used to describe situations that are not normal or extraordinary events, so that the authors use many words that have the same basic meaning with different connotations. In other words, words that have the same basic meaning are used to emphasize the event that is described. This can be seen in the first and second verses with expressions of gripping horror that engulf all nature and isolation, hiding unbearable fear. Pleonasm is very appropriate to be used to construct a discourse on extraordinary events as expressed by the author. This expression shows the spirit of the author, who is afraid to see the global Covid-19 pandemic.

Metaphorical language is a direct comparison of two different things. This figure of speech is used by the author to generate poetic value and build the reader's imagination. This figure is used in the second and fourth verse of the song "Virus Corona". In the second couplet, it is used in the line Almost in every land they close themselves, while in the fourth couplet it can be seen in the array The eyes of the world open how weak humans are. The use of metaphorical figures in the second and fourth couplets, in addition to creating poetic and expressive aspects, also builds the reader's imagination towards the enormity of the extraordinary event, namely the Covid-19 pandemic.

The litotes in song lyrics make a sublime or special atmosphere in the midst of the very frightening atmosphere of the Covid-19 pandemic. This is because the litotes figure is a figure of speech that reveals a decrease in quality to humble oneself. This verse is used by the author very precisely, namely to build a sublime and sacred atmosphere in praying to God. This is because the authors believe that the emergence of this global pandemic was also wanted by God. Therefore, the author begs God to protect himself as well as stop this global pandemic. 
The straightforward sentence style with the rhetorical means of pleonasm, matafora, and litotes is used to build a whole discourse, namely how to respond to the global pandemic caused by the Coronavirus. From the beginning to the end, the lyrics of the song build the discourse in order.

\section{Conclusions}

From the description above, it can be concluded that the language style that builds the lyrics of the song "Virus Corona" cannot be separated from the stylistic units of building song lyric discourse. This is because the lyric discourse of the song is built by the smallest elemental unit, namely the sound until the complete lyric discourse is built. The aesthetic sound style is closely related to the style of the word. Sentence style is also closely related to units of style and or smaller elements, namely sound and diction. With the addition of rhetorical devices in the form of pleonasm, metaphor, and litotes, rhetorical discourse becomes more beautiful. This style of language is very appropriate for building discourse with full moral messages. This is because the lyrics of the song "Virus Corona" strongly emphasizes a moral message.

\section{References}

1. G. W. Turner, Stylistic, (Penguin Books Harmonsworth, 1977)

2. M. Muzakka, Kritik Sosial dalam Lirik Lagu “Indonesia” Karya Rhoma Irama”, (2019)

3. M. Muzakka, Keresahan Rhoma Irama terhadap Perempuan di Sektor Publik: Kajian terhadap Lirik Lagu 'Emansipasi Wanita, Jurnal NUSA, 14(4), (2019)

4. M. Muzakka, Nilai-Nilai Profetik dalam Dua Lirik Lagu Karya Rhoma Irama: Kajian terhadap Lirik Lagu "Akhlak" dan "Virus Corona”, Jurnal NUSA, 15(1), (2020)

5. R. D. Pradopo, Stilistika, Jurnal Humaniora, (1994)

6. U. Junus, Stilistik: Satu Pengantar, (Dewan Bahasa dan Pustaka Kuala Lumpur, 1989)

7. N. K. Ratna, Estetika Sastra dan Budaya, (Pustaka Pelajar Yogyakarta, 2015)

8. R. D. Pradopo, Gaya Bunyi, Jurnal Humaniora, (1997)

9. H. Kridalaksana, Kamus Linguistik, (Gramedia Jakarta, 1982)

10. M. Mussaif, Muzakka, Beginilah Meneliti Sastra, (Sint Publishing Semarang, 2018)

11. P. W. J. Nababan, Sosiolinguistik: Suatu Pengantar, (PT Gramedia Pustaka Utama Jakarta, 1991)

12. Slametmuljana, Peristiwa Bahasa dan Peristiwa Sastra, (Ganaco Bandung-Jakarta, 1956) 